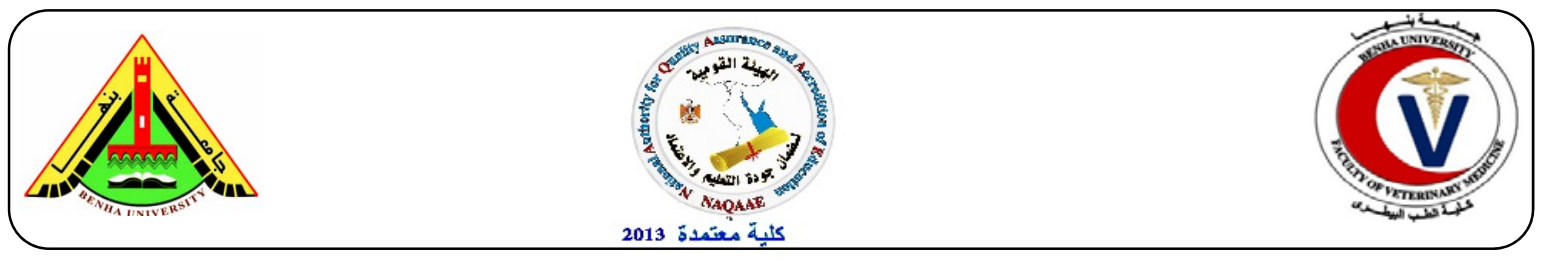

\title{
Molecular characterization of Aminoglycosoide and Tetracycline resistant Salmonella isolates causing new born ruminants diarrhea
}

\author{
Ashraf A. Abd El- Twab ${ }^{1}$, Fatma I. El-Hofy ${ }^{1}$, Amira Mohamed Rizk ${ }^{1}$ \\ ${ }^{1}$ Department of Bacteriology, Immunology and Mycology, Faculty of Veterinary Medicine, Moshtohor, \\ Benha University. Amira.Rizk01@,fvtm.bu.edu.eg
}

\begin{abstract}
A B S T R A C T
Ten isolates of Salmonella species were obtained from sporadic cases of profuse diarrhea in new born ruminants from El-Menofiya and El-Kalubia Governorates in Egypt. These isolates were as follow 7 isolates from calves (Salmonella Typhimurium, Salmonella Enteritidis,two were Salmonella Saintpaul, two were Salmonella Langeveld and Salmonella Havana), two isolates from lambs (Salmonella Typhimurium, Salmonella Bardo) and one isolate from goat-kids(Salmonella Enteritidis). Salmonella isolates resistance to aminoglycosoides was $0.00 \%$ for Amikacin, $30 \%$ for tobramycin and $50 \%$ for streptomycin. Susceptibility of isolates to tetracycline was $50 \%$ for doxycycline. Results showed a high incidence of aminoglycosoides resistance gene aadB in $100 \%$ of the isolates while aadA2 genes in $40 \%$ of the isolates. Incidence of tetracycline resistance genes was $0.00 \%$ for tet $A(B)$ and $80 \%$ for tet $A(A)$. The difference between the results of this study and those from other regions in Egypt necessitate a complete survey overall the country to make a complete and clear map of salmonella servoars, their antibiotics susceptibility and in molecular characterization of resistance determinants in each region.
\end{abstract}

Key words: Diarrhea, newborn ruminants, Salmonella, aminoglycosoides, tetracycline.

(http://www.bvmj.bu.edu.eg)

(BVMJ-30(1): 161-170, 2016)

\section{INTRODUCTION}

$\mathrm{W}$ ith the extensive and widespread application of antibiotic as a therapeutic agent in animals and human, and as a growth promoter in livestock, bacteria have been exposed to sub-inhibitory (non-lethal) dose of antibiotics (Singh et al., 2015). This has played critical role in the evolution of antibiotic resistance (Andersson and Hughes 2014), and selection of antibiotic resistant bacteria (Gullberg et al., 2011). The efficacy of many antimicrobials drugs for treating clinical cases is decreasing as more antimicrobial resistant Salmonella subtypes emerge (Angulo et al., 2000 and Winokur et al., 2000). Studying of resistance determinants with molecular and genetic methods have a critical role in understanding, controlling, and spreading of resistant pathogens. Aminoglycosides are the most frequently used antibiotic agents in the treatment of infections by both Gram-negative and Gram-positive bacteria (Samadi et al., 2015). This group of antibiotics acts by binding to the ribosomes of bacteria and in turn interferes with protein synthesis (Mingeot et al., 1999). The aminoglycoside-bound bacterial ribosome is unavailable for translation of mRNA during protein synthesis thereby causing bactericidal effects (Le Goffic et al., 1979). Aminoglycoside resistance of Salmonella strains is generally associated with expression of aminoglycosidemodifying enzymes (Alcaine et al., 2007). Beside binding to ribosomal 30S subunit, Streptomycin has been shown to perturb the structure of the decoding centre, while other 
aminoglycosides such as paromomycin affect conformations of the 16S rRNA bases directly involved in decoding (Carter et al., 2000; Demirci et al., 2013). Bacterial resistance to aminoglycosides can be acquired through different mechanism including decreased uptake of aminoglycosides into the cell via decreased cell-membrane permeability, reduction of the drug concentration in the cell by efflux pumps development, alteration of the drugbinding site by mutation or chemical modification of the 16S RNA or ribosomal proteins, and enzymatic modification of aminoglycosides, leading to drug inactivation and diminished binding (Azucena \& Mobashery, 2001, LlanoSotelo et al., 2002). Enzymatic modification of aminoglycosides is mediated by three types of modifying enzymes, aminoglycoside Onucleotidyltransferases (ANTs), aminoglycoside $\quad \mathrm{N}$-acetyltransferases (AACs) and aminoglycoside Ophosphotransferases (APHs). In salmonella enteric AadA was recently characterized to be an ANT (3") (9) streptomycin / spectinomycin adenyl transferase encoded by the aadA gene that adenylates the 3hydroxyl group of the streptomycin glucosamine ring and the 9-hydroxyl group of the spectinomycin actinamine ring (Chen et al., 2015). Tetracycline act by inhibiting protein synthesis. They enter bacterial cells by an energy-dependent process and bind reversibly to the A site of the $30 \mathrm{~S}$ ribosomal subunits of the bacteria. (Mascaretti 2003). This process blocks the access of aminoacyl-tRNA to the RNA-ribosome complex, preventing bacterial polypeptide synthesis therefore it inhibits protein synthesis (Chopra et al., 1992). Tetracycline resistance results from acquisition of exogenous DNA encoding proteins involved in active efflux of tetracycline or in protection of the ribosome. Resistance to tetracycline is prominent among $\mathrm{S}$. Typhimurium isolates in humans $(34 \%)$, chickens $(39 \%)$, cattle $(59 \%)$, and swine $(88 \%)$ according to a ten- year average from the National Antimicrobial Resistance Monitoring System CDC (2012) and FDA (2011). In Gram-negative bacteria, six classes of tet efflux pumps including tet $\mathrm{A}$, tet $\mathrm{B}$, tet $\mathrm{C}$, tet $\mathrm{D}$, tet $\mathrm{E}$, tet $\mathrm{G}$, are of clinical importance. These tetracycline resistance genes conferred efflux of tetracycline from the cell and encoded the first of the three different types of tetracycline resistance mechanisms to be found in bacteria (Roberts 1996). These efflux pumps use an antiport mechanism of transport involving the exchange of a proton for tetracyclinecation complex (Lyras and Rood. 1996). Isolates of various Salmonella enterica subsp. enterica serovars of zoonotic or veterinary importance showed high levels of tetracycline resistance. Among S. Dublin (Ferris et al. 1992) and S. Choleraesuis (Weide-Botjes 1998) from the USA, 65\% and $89 \%$ of the isolates proved to be resistant to tetracyclines. Tetracycline resistance among $\mathrm{S}$. Typhimurium isolates seemed to vary according to the animal source and the geographical origin of the isolates (Gnanou 1998).

This study aimed to characterize the prevalence, serotypes and genetic determinants of aminoglycosoides and tetracycline resistant salmonella serovars causing diarrhea in new born animal in ElMenofiya and El-Kalubia Governorates, Egypt.

\section{MATERIAL AND METHODS:}

\subsection{Samples Collection}

A Total of 236 fecal swabs were collected from diarrheic Calves (150 cases), lamb (55cases) Goat kids (31cases) as sporadic cases presented in Governmental Veterinary Clinics in El-Menofiya and ElKalubia Governorates, Egypt.

\subsection{Isolation and Identification of salmonella}

Swabs were suspended in buffered peptone water (1:10 dilution) then incubated at $37^{\circ} \mathrm{C}$ (16-20 hours). Then incubated buffered 
peptone water $(0.1 \mathrm{ml})$ was transferred with a pipette into a tube containing $(10 \mathrm{ml})$ of Rappaport-Vassiliadis soy peptone (RVS) broth and incubated at $42^{\circ} \mathrm{C}(20-24$ hours). After that, a loopfull of RVS broth was inoculated and streaked separately onto selective agar plates as Xylose Lysine Desoxycholate (XLD) agar, Brilliant Green agar (BGA), MacConkey's agar then incubated at $37^{\circ} \mathrm{C}$ for $24-48 \mathrm{~h}$. Typical colonies of Salmonella on XLD agar were pale pink with black center and on MacConkey's agar appear pale, colorless smooth and transparent. Suspected colonies were identified as Salmonella spp. based on their colony characters on selective media, and the biochemical testing using TSI agar, Urea agar, L-lysine decarboxylase, Voges Proskauer, Methyl red tests, Simmons citrate and Indole tests. Also, Salmonella spp. were confirmed biochemically by using API 20E system (BioMérieux, Marcy-l'Étoile, France). Finally, Salmonella isolates were serotyped based on slide agglutination for $\mathrm{O}$ and $\mathrm{H}$ antigens according to Kauffmann-White (1974) and using the antisera from (Mast Salmonella diagnostic antisera) (UK).

\subsection{Antimicrobial sensitivity}

The antimicrobial sensitivity phenotypes of Salmonella were determined by agar disc diffusion method as described by Finegold and Martin (1982), and according to the guidelines of the Clinical and Laboratory Standards Institute (CLSI, 2014), using antibiotic disc from Oxoid (Thermo Fisher Scientific, Inc. (NYSE: TMO, UK). The discs used were amikacin $(30 \mu \mathrm{g})$, tobramycin $(10 \mu \mathrm{g})$, streptomycin $(10 \mu \mathrm{g})$, doxycycline $(30 \mu \mathrm{g})$ (Oxid, UK).

\subsection{Bacterial DNA preparation for PCR}

Bacterial culture DNA was extracted using the (QIAamp DNA extraction mini kit) (QIAGEN. Duesseldorf, Germany, (Egypt branch) according to the mini kit instructions $(200 \mu \mathrm{l})$ of an overnight bacterial culture was mixed with $200 \mu$ l buffer plus $20 \mu \mathrm{l}$ QIAGEN protease in 1.5 $\mathrm{ml}$ tube, mixture was incubated at $56^{\circ} \mathrm{C}$ for
$10 \mathrm{~min}$, then $200 \mu \mathrm{l}$ ethanol $(96 \%)$ were added, vortexing for 15 seconds, applied to the QIAamp mini spin column, centrifugated at $8000 \mathrm{rpm}$ for $1 \mathrm{~min}$, washed two time with washing buffer and DNA was eluted from the column with $150 \mu \mathrm{l}$ buffer AE elution buffer.

\subsection{Amplification of Antibiotic Resistant genes in salmonella serovars}

PCR mixture was prepared According to Emerald Amp GT PCR mastermix (Takara, Co., Japan). Code No. RR310A kit: In PCR tube a $6 \mu 1$ bacterial DNA template, $12.5 \mu 1$ Emerald Amp GT PCR master mix (2x premix), $1 \mu 1$ of forward and reverse primers $(20 \mathrm{pmol})$ and $4.5 \mu \mathrm{l}$ PCR grade water to bring total volume to 25 . was primary denaturation cycle at $94^{\circ} \mathrm{C}$ for 5 min followed by 35 cycle of $94^{\circ} \mathrm{C}$ for 30 secs, $53^{\circ} \mathrm{C}$ for 45 The amplification condition sec and $72^{\circ} \mathrm{C}$ for $45 \mathrm{sec}$ followed by one final extension cycle at $72^{\circ} \mathrm{C}$ for 10 min using the primers sequence and amplification conditions listed in table (1)

\section{RESULTS}

A total of 236 fecal samples collected from diarrheic newborn ruminants were screened for the presence of Salmonella species. Identification procedures (cultivation, isolation, biochemical and serological tests) identified ten isolates of Salmonella species as 7 isolates from calves (Salmonella Typhimurium, Salmonella Enteritidis, two were Salmonella Saintpaul, two were Salmonella Langeveld and Salmonella Havana), 2 isolates from lambs (Salmonella Typhimurium, Salmonella Bardo) and one isolate from goat-kids (Salmonella Enteritidis). Salmonella isolates showed $0.00 \%, 30 \%$ and $50 \%$ resistance to amikacin, tobramycin and streptomycin respectively. The resistance to doxycycline was $50 \%$ (Table 2). Aminoglycosoide resistance gene (aadB) was detected in all Salmonella isolates (Table 3) showing amplification of $319 \mathrm{bp}$ 
(Figure 1) while the (aadA2) was detected only in $40 \%$ of isolates (S. Saintpaul No.73, S. Langeveld No.67 and 96 and S. Typhimurium No.10,) Figure (2) showing amplification of $622 \mathrm{bp}$. Tetracycline resistance gene tetA (A) was detected in
$80 \%$ of isolates but was not detected in S. Typhimurium No.99 and S. Havana No.133 Figure (3) showing amplification of 576bp. Tetracycline resistance gene tetA (B) was not detected in any of the isolates Figure (4).

Table (1). Primers used to amplify aminoglycosoides and tetracycline resistance genes

\begin{tabular}{llcc}
\hline Primer & \multicolumn{1}{c}{ Sequence } & Product size & Reference \\
\hline aadB & GAGCGAAATCTGCCGCTCTGG & $319 \mathrm{bp}$ & \\
& CTGTTACAACGGACTGGCCGC & & Frana et al., 2001 \\
\multirow{2}{*}{ aadA2 } & TGTTGGTTACTGTGGCCGTA & $622 \mathrm{bp}$ & \\
& GATCTCGCCTTTCACAAAGC & & Walker et al., 2001 \\
\multirow{2}{*}{ tetA(A) } & GGTTCACTCGAACGACGTCA & $576 \mathrm{bp}$ & \\
& CTGTCCGACAAGTTGCATGA & & \\
\multirow{2}{*}{ tetA(B) } & CCTCAGCTTCTCAACGCGTG & $633 \mathrm{bp}$ & Randall et al., 2004 \\
& GCACCTTGCTCATGACTCTT & & \\
\hline
\end{tabular}

Table (2). Sensitivity of the Salmonella Serotypes isolated from diarrheic calves, lamb and goat kids to aminoglycosides and Tetracycline

\begin{tabular}{|c|c|c|c|c|c|}
\hline \multirow{3}{*}{ Salmonella } & & \multicolumn{4}{|c|}{ Zone of inhibition due to aminoglycoside discs in each S. } \\
\hline & & \multirow{2}{*}{ Amikacin } & \multicolumn{2}{|c|}{ Serovars } & \multirow[b]{2}{*}{ Doxycycline } \\
\hline & & & Tobramycin & Streptomycin & \\
\hline Calves serovar & isolate & & & & \\
\hline S. Typhimurium & 99 & (24) $\mathrm{S}$ & $(18) \mathrm{S}$ & (19) $\mathrm{S}$ & (19) $\mathrm{S}$ \\
\hline S. Enteritidis & 103 & $(18) \mathrm{S}$ & (14) I & (19) $\mathrm{S}$ & (19) $\mathrm{S}$ \\
\hline S. Saintpaul & 62 & (20) $\mathrm{S}$ & (10) R & (17) $\mathrm{S}$ & (17) $\mathrm{S}$ \\
\hline S. Saintpaul & 73 & (26) $\mathrm{S}$ & (18) $\mathrm{S}$ & (10) R & (10) R \\
\hline S.Langeveld & 67 & (20) $\mathrm{S}$ & $(18) \mathrm{S}$ & $(10) \mathrm{R}$ & $(10) \mathrm{R}$ \\
\hline S. Langeveld & 96 & (23) $\mathrm{S}$ & (17) $\mathrm{S}$ & (8) $\mathrm{R}$ & (8) $\mathrm{R}$ \\
\hline S. Havana & 133 & (18) $\mathrm{S}$ & (14) I & (10) R & (10) $\mathrm{R}$ \\
\hline Lambs serovar & 10 & (20) $\mathrm{S}$ & (9) R & $(-) \mathrm{R}$ & $(-) \mathrm{R}$ \\
\hline \multicolumn{6}{|l|}{ S. Typhimurium } \\
\hline S. Bardo & 27 & (21) $\mathrm{S}$ & (12) R & (17) $\mathrm{S}$ & (17) $\mathrm{S}$ \\
\hline Goats kids serovar & 25 & (17) $\mathrm{S}$ & (18) $\mathrm{S}$ & (19) S & (19) S \\
\hline \multicolumn{6}{|c|}{ S. Enteritidis } \\
\hline \multicolumn{2}{|c|}{ Number of resistant serovars } & 0 & 3 & 5 & 5 \\
\hline \multirow{2}{*}{\multicolumn{2}{|c|}{$\begin{array}{l}\text { Percentage of resistant } \\
\text { Serovars }\end{array}$}} & 0.00 & $30 \%$ & $50 \%$ & $50 \%$ \\
\hline & & & & & \\
\hline
\end{tabular}

-Number in brackets: size of inhibition zone with mm. -R: resistant, S: sensitive, I: intermediate. according to (CLSI 2014) 
Table (3) Incidence of aminoglycosides and tetracycline resistance genes in Salmonella isolates

\begin{tabular}{|c|c|c|c|c|c|}
\hline \multirow[b]{2}{*}{ S. Serovars } & \multirow{2}{*}{$\begin{array}{l}\text { Isolate } \\
\text { number }\end{array}$} & \multicolumn{4}{|c|}{ Genes } \\
\hline & & $\operatorname{aadB}$ & aadA2 & $\operatorname{tet} A(\mathrm{~A})$ & tetA(B) \\
\hline Calves & 99 & + & - & - & - \\
\hline S. Typhimurium & & & & & \\
\hline S. Entritidis & 103 & + & - & + & - \\
\hline S. Saintpaul & 62 & + & - & + & - \\
\hline S. Saintpaul & 73 & + & + & + & - \\
\hline S.Langeveld & 67 & + & + & + & - \\
\hline S. Langeveld & 96 & + & + & + & - \\
\hline S. Havana & 133 & + & - & - & - \\
\hline Lambs & 10 & + & + & + & - \\
\hline S. Typhimurium & & & & & \\
\hline S. Bardo & 27 & + & - & + & - \\
\hline $\begin{array}{l}\text { Goats kids } \\
\text { S. Entritidis }\end{array}$ & 25 & + & - & + & - \\
\hline
\end{tabular}

\begin{tabular}{|l|l|l|l|l|l|l|l|l|l|l|l|l|l|l|l|l|l|}
\hline 6 & 5 & 4 & Pos & $\tilde{\mathbf{L}}$ & $\mathbf{3}$ & $\mathbf{2}$ & $\mathbf{1}$ & $\mathrm{Neg}$ & $\mathrm{Neg}$ & $7^{m}$ & Pos & $\mathbf{L}^{\sim}$ & Pos & $\tilde{8}$ & $\mathbf{9}$ & $\mathbf{1 0}$ & Neg \\
\hline
\end{tabular}

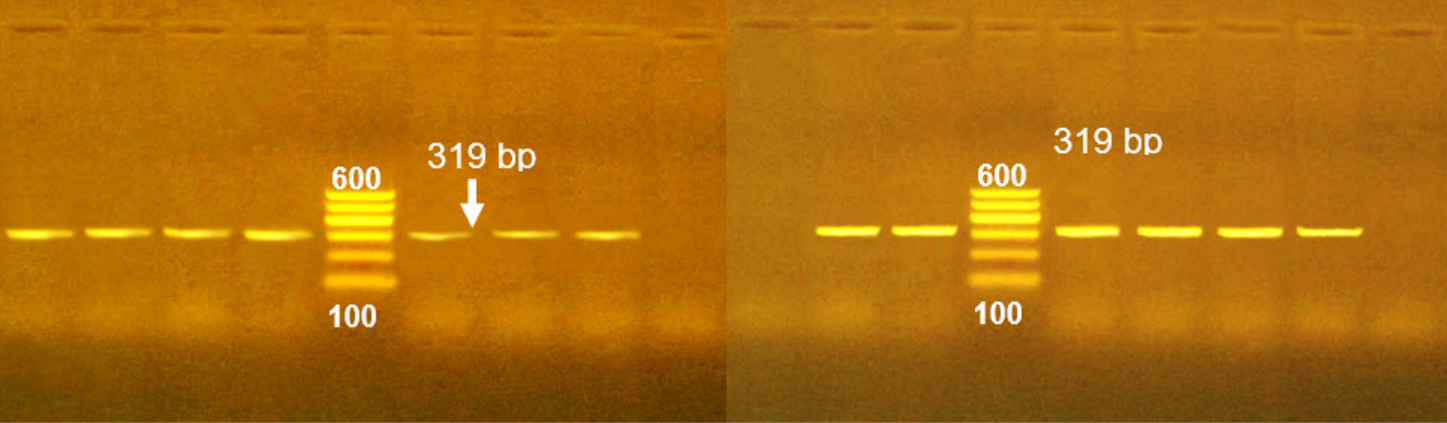

Figure (1):PCR detection of aminoglycosoides resistance gene (aadB) in different salmonella isolates

L (DNA ladder), Neg (Negative control), Pos (Positive control), (1-7) Salmonella isolates from Diarrheic calves: 1,3 (S. Saintpaul), 2,4 (S. Langeveld)) ,5 (S. Typhimurium) ,6 (S. Havana), 7 (S. Entritidis), (8, 10) Salmonella isolates from diarrheic lambs :8 (S. Typhimurium), 10 (S. Bardo), 9 (S. Entritidis) from diarrheic goat kids.
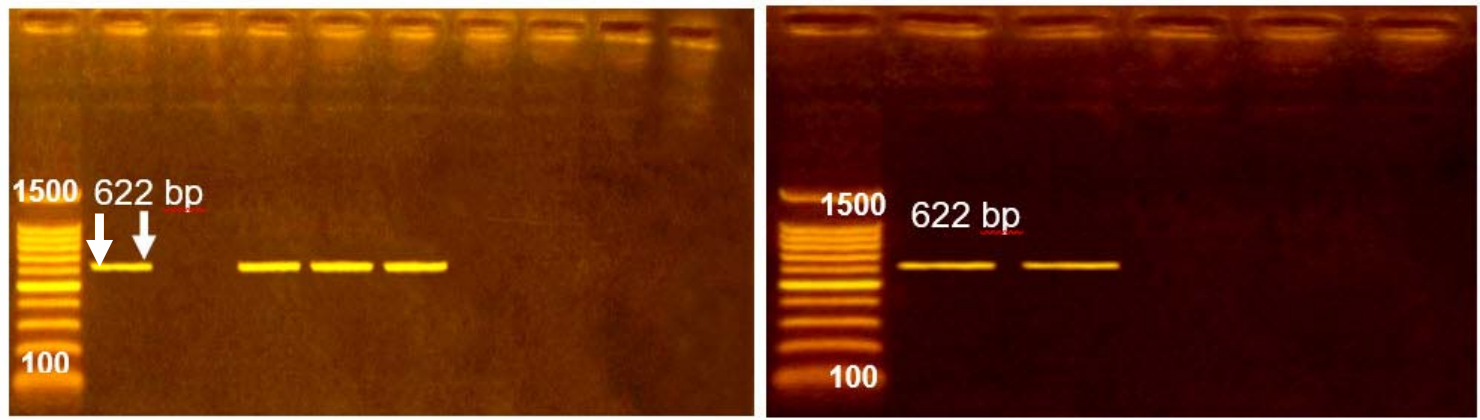

Figure(2):PCR detection of aminoglycosoide resistance gene (aadA2) in Salmonella isolates 


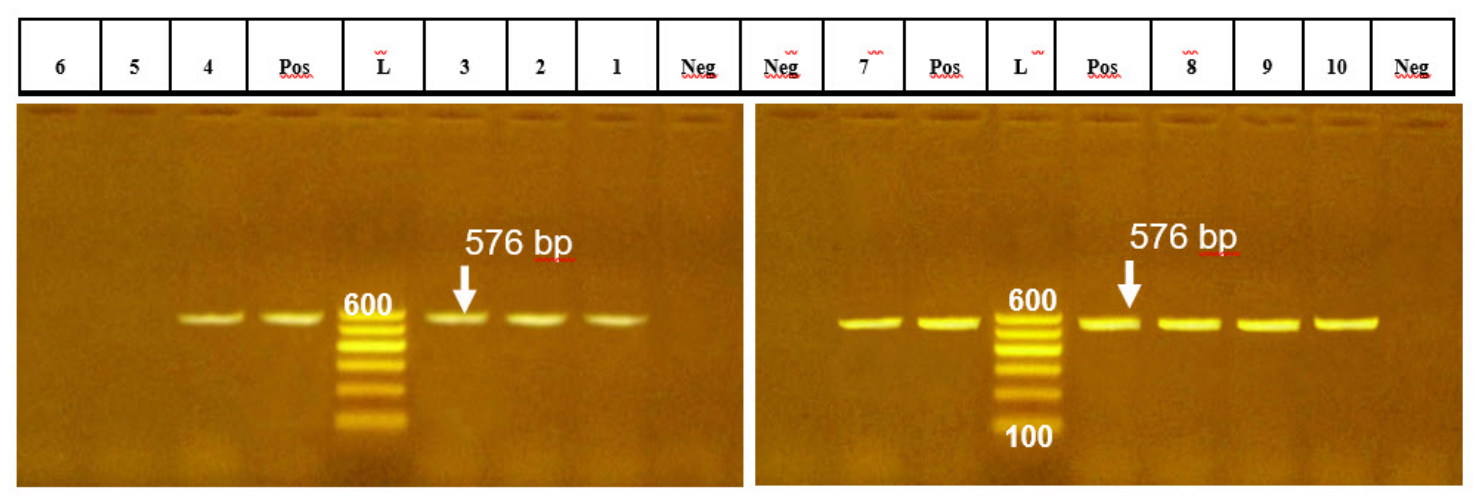

Figure (3): PCR detection of tetracycline resistance gene (tetA) in salmonella isolates

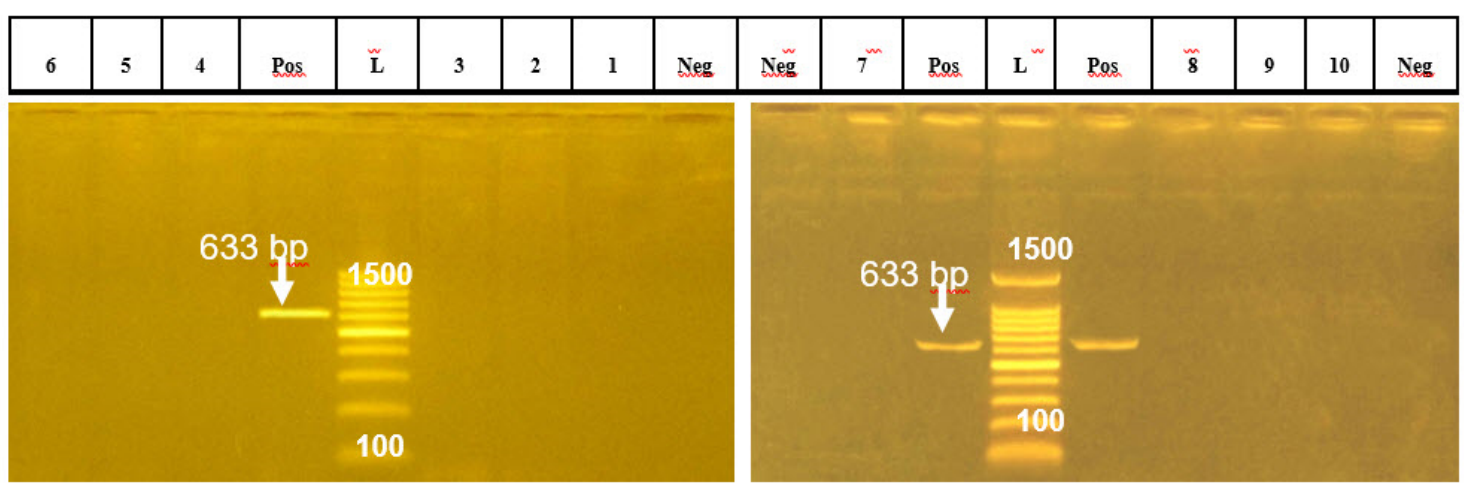

Figure (4): PCR detection of one tetracycline resistance gene (tetB) in salmonella isolates.

L (DNA ladder), Neg (Negative control), Pos (Positive control), (1-7) Salmonella isolates from Diarrheic calves: 1, 3 (S. Saintpaul), 2,4 (S. Langeveld)), 5 (S. Typhimurium) ,6 (S. Havana), 7 (S. Entritidis), (8, 10) Salmonella isolates from diarrheic lambs :8 (S. Typhimurium), 10 (S. Bardo), 9 (S. Entritidis) from diarrheic goat kids.

\section{DISCUSSION}

The use of antibiotics based on earlier report of their effectiveness may not be effective at all times (Kumar et al., 2012). Given the increasing prevalence of Salmonella isolates resistant to antibiotics, make it mandatory to investigation over different geographical region and continuous periodical search for the prevalence of newly emerged drug-resistant salmonella strains and their MDR determinants. Based on historical evidence, continued emergence of AMR and/or virulent subtypes can be expected. Therefore, additional epidemiologic and molecular research should be directed towards the entire population to understand the epidemiology, ecology and evolution associated with changes in the prevalence of AMR Salmonella within livestock populations (Habing 2012). This study aimed to investigate the prevalence of salmonella species in the sporadic cases of diarrheic calves, lambs and goat kids in the middle of Egypt and to identify their serotypes in addition to determination of their sensitivity or resistant to aminoglycosoide and tetracycline and to characterizes the determinant of their resistance to these antibiotics.

Susceptibility of different salmonella to members of aminoglycosoides showed that the resistance varies between $0.00 \%$ to Amikacin, 30\% to Tobramycin and 50\% to Streptomycin Table (2). This result is 
completely different from that of a previous result showed that $100 \%$ of Salmonella enterica isolated from clinically diarrheic human in Egypt are resistance to Streptomycin (Osman et al., 2014). Moreover, other study in a different region on chicken meat and clinical human cases in Egypt, 25\% and $66.7 \%$ of salmonella isolates were resistance to Streptomycin and gentmycin respectively (Gharieb et al 2015). There is a close relation between animal serovars and that isolated from human in each region as considerable number of serotypes frequently isolated from humans have been isolated from sick or clinically healthy cattle (Hoelzer et al., 2011). Therefore the difference in the susceptibility to aminoglycosoides could be related to the difference in sampling region and the previous antibiotic stress facing the salmonella serovars in our sampling region than others'. Indeed, selective pressure favors the emergence of antimicrobial resistance pathogens such as Salmonella, which is frequently harbored in the animal intestinal tract (Aarestrup 2000). In this study, this difference in the susceptibility of salmonella isolates may be also due to the incidence of the aminoglycosoides resistance genes as aadB genes was detected in $100 \%$ of the isolates while aadA2 was detected only in $40 \%$ of the isolates Table (3). The aadA2 is a one of the gene cassettes containing aminoglycoside acetyltransferase which confers resistance against streptomycin and spectinomycin (Gharieb et al 2015). Therefore, the detection of the aadA2 is in consistence with the susceptibility of the salmonella isolates to streptomycin. In a recent study in Ghana, bacterial isolates including salmonella showed resistance levels of $<50 \%$ for amikacin and gentamicin (Opintan et al., 2015). However, in the current study, salmonella isolates resistance to amikacin was $0.00 \%$. This difference may be attributed to the difference of the previous use of amikacin between the two countries. Parallel to our finding a recent study showed salmonella isolates susceptibility to amikacin and gentamicin was $98-99 \%$ (Reshetneva et al., 2015). This results is further strengthened by report from Turkey showing Salmonella Enteritidis isolated from human feces susceptibility is $100 \%$ to amikacin and gentamicin (Acar et al., 2015).

Susceptibility of different salmonella isolates to the tetracycline (Doxycycline) showed that the resistance $50 \%$ to Doxycycline table (2). In antimicrobial susceptibility tests of salmonella isolates from farm animals in China, Salmonella spp. resistance to doxycycline were $(28.22 \%)$, and to were tetracycline (27.58\%) (Kuang et al.,2015). Resistance to tetracycline of isolates from gastroenteritis human patients from Minia governorate, Egypt was $77 \%$ which is higher than our finding (Mahmoud et al., 2015). While in a study of salmonella Typhi cultured from blood from patient from Cairo governorate, Egypt, it was reported that salmonella Typhi resistance to tetracycline was 35\% (Wasfy et al., 2002). Thus the resistant pictures vary from region to region in Egypt that may reflect the general or specific antibiotic previous exposure and stress on the microorganism and emergence of different levels of resistance in each region. In spite of the $50 \%$ resistance to tetracycline the expression of tetA gene was detected in only $40 \%$ of the isolates while tetB could not be detected in any isolates Table (3). Indeed, it was reported that not all resistant isolates of non typhoid salmonella express the tetB genes (Mahmoud et al., 2015). This may imply that tet $A$ or tet $B$ are not the only genes responsible for salmonella resistance to tetracycline. The tetracycline resistance genes are tet $A$, tet $B$, tet $C$, tet $D$, tet $E$, tet $G$, tetK, tetL, tetM, tet $O$, tetS, tetA $(P)$, tetQ, and text (Andrew et al.,2004). tetB gene was only detected by PCR in $64.7 \%$ of tetracycline resistant non typhoid isolates from gastroenteritis human patients ((Mahmoud et al., 2015). 


\section{CONCLUSION}

In this study, the susceptibility of the isolates to aminoglycosoides is higher than that to Tetracycline. This make amikacin is the drug of choice to treat suspected or confirmed salmonella infection at least in the region of this study. The difference between the results of the current study and those from other regions in Egypt necessitate a complete survey overall the country to make a complete and clear map of the servoars and their antibiotics susceptibility in addition molecular characterization of resistant determinants in each region.

\section{REFERENCES:}

Aarestrup, F.M. 2000. Occurrence, selection and spread of resistance to antimicrobial agents used for growth promotion for food animals in Denmark. APMIS Suppl. 101:1-48.

Acar, S., Levent, B., Atalan, E. 2015. A molecular epidemiological investigation of multistate outbreaks of Salmonella Enteritidis from clinical and environmental samples in Turkey, 2000-2010.Turk. J. Med. Sci. ,45(1): 76-83.

Alcaine, S.D., Warnick, L.D., Wiedmann, M. 2007. Antimicrobial resistance in ontyphoidal Salmonella. J Food Protection. 70: 780-790.

Andersson, D.I., Hughes, D. 2014. Microbiological effects of sublethal levels of antibiotics. Nat Rev Microbiol 12: 465-478.

Andrew Bryan, Nir Shapir, Michael, J., Sadowsky. 2004. Frequency and Distribution of Tetracycline Resistance Genes in Genetically Diverse, Nonselected, and Nonclinical Escherichia coliStrains Isolated from Diverse Human and Animal Sources. Appl. Environ. Microbiol. 70: 2503-2507.
Angulo. 2000. Emergence of domestically acquired ceftriaxone-resistant Salmonella infections associated with AmpC beta-lactamase. JAMA 284: 3151-6.

Azucena, E., Mobashery, S. 2001. Aminoglycoside-modifying enzymes: mechanisms of catalytic processes and inhibition. Drug Resist Updat.,4(2): 106-17.

Carter, A.P., Clemons, W.M., Brodersen, D.E., Morgan-Warren, R.J., Wimberly, B.T., Ramakrishnan, V. 2000. Nature (London), 407: 340348.

CDC. 2012. National Antimicrobial Resistance Monitoring System for Enteric Bacteria.

Chaslus-Dancla, E., Lafont, J.P.1985. Resistance to gentamicin and apramycin in Escherichia coli from calves in France, Vet. Rec. 117: 9091.

Chen, Y., Näsvall, J., Wu, S., Andersson, D.I., Selmer, M. 2015. Structure of aadA from Salmonella enterica: a monomeric aminoglycoside (3")(9) adenyltransferase. Acta Crystallogr D Biol Crystallogr. 71: 2267-77.

Chopra, I., Hawkey, P.M., Hinton, M. 1992.Tetracyclines, molecular and clinical aspects.J. Antimicrob. Chemother., 29(3): 245-77.

CLSI.2014. Clinical and Laboratory Standards Institute antimicrobial susceptibility testing standards M100-S24 Performance Standards for Antimicrobial Susceptibility Testing; Twenty- Fourth Informational Supplement (http://clsi.org/wp-content /uploads /sites/14/2014/12 /CLSI Fall 2014_Catalog_Web1.pdf).

Demirci, H., Murphy, F., Murphy, E., Gregory, S.T., Dahlberg, A.E., Jogl, G. 2013. A structural basis for streptomycin-induced misreading of 
the genetic code,Nature Commun. 4: 1355-1362.

FDA . 2011. National Antimicrobial Resistance Monitoring System Enteric Bacteria (NARMS): 2009 Executive Report. Rockville, MD: U.S. Department of Health and Human Services, Food and Drug Administration.

Ferris, K.E., Andrews, R.E.Jr., Thoen, C.O., Blackburn, B.O. 1992. Plasmid profile analysis, phage typing, and antibiotic sensitivity of Salmonella dublin from clinical isolates in the United States. Veterinary Microbiology 32(1): 51- 62.

Finegold, S.M., Com, Martin, W.J. 1982. Diagnostic microbiology.6th Ed, The C.V. Mosby pany ,St. Louis, Toronto,London.

Frana, T.S., Carlson, S.A. Griffith, R.W. 2001. Relative distribution and conservation of genes encoding aminoglycoside-modifying enzymes in Salmonellaenterica serotype

Typhimurium phage type DT104. Applied and Environmental Microbiology 67: 445-8

Gharieb, R.M., Tartor, Y.H., Khedr, M.H. 2015. Non-

Typhoidal Salmonella in poultry mea $\mathrm{t}$ and diarrhoeic patients:prevalence, antibiogram, virulotyping, molecular detection and sequencing of class I integrons in multidrug resi stant strains. Gut Pathog. 7: 34-44.

Gnanou, J.C. 1998. Antibiotic resistance in bacteria from animal origin. Analysis of National Monitoring Programs 1997, CNEVA, Fougères.

Gullberg, E., Cao, S., Berg, O.G., Ilback, C., Sandegren, L., Hughes, D.2011. Selection of resistant bacteria at very low antibiotic concentrations. PLoS Pathog 7 (7): e1002158. doi: 10.1371

Habing, G.G. 2012. Genotypic and antimicrobial resistance trends in salmonella on Michigan dairy farms. A dissertation Michigan State Univ.
Comparative Medicine and Integrative Biology. pp.197 .

Hoelzer, K., Cummings, K.J., Wright, E.M., Rodriguez-Rivera L.D., Roof, S.E., Switt, A.I., Dumas, N., Root, T., Schoonmaker-Bopp, D.J., Grohn, Y.T., Siler, J.D., Warnick, L.D., Hancock, D.D., Davis, M.A., Wiedmann, $\quad$ M. 2011. Salmonella Cerro isolated over the past twenty years from various sources in the US represent a single predominant pulsed-field gel electrophoresis type. Vet. Microbiol. 150(3-4): 389-93.

Kauffman, F. 1974. Serological diagnosis of Salmonella species. Kauffman White Scheme, Copenhagn, Denmark.

Kuang, X., Hao, H., Dai, M., Wang, Y., Ahmad, I., Liu, Z., Zonghui ,Y. 2015. Serotypes and antimicrobial susceptibility of Salmonella spp. isolated from farm animals in China. Front Microbiol. 6: 602-612

Kumar, T., Mahajan, N.K., Rakha, N.K. 2012. Isolation and prevalence of Salmonella serovars from poultry in different parts of Haryana, India. Indian J. Anim. Sci., 82: 557-560.

Le Goffic, F., Capmau, M.L., Tangy, F., Baillarge, M. 1979. Mechanism of action of aminoglycoside antibiotics. Binding studies of tobramycin and its 6'-Nacetyl derivative to the bacterial ribosome and its subunits. Eur. J. Biochem. 102:73-81.

Llano-Sotelo, B., Azucena, E.F.Jr., Kotra, L.P., Mobashery, S., Chow, C.S. 2002. Aminoglycosides modified by resistance enzymes display diminished binding to the bacterial ribosomal aminoacyl-tRNA site. Chem. Biol. 4: 455-63.

Lyras, D., Rood, J.I. 1996. Genetic organization and distribution of tetracycline resistance determinants in Clostridium perfringens. Antimicrob. Agents Chemother. 40: 2500-4. 
Mahmoud Shokry Mahmoud, Mona Abdel Monem Esmail, Rasha, M.M. Khairy, Omnia, S., Mazher. 2015. Detection of Multi-Drug Resistant NonTyphoid Salmonella Isolates in Cases of Gastroenteritis in Egypt. British Microbiology Research Journal. 6 (3): 167-174.

Mingeot-Leclercq, M.P., Glupczynski, Y., Tulkens, P.M. 1999. Aminoglycosides: activity and resistance. Antimicrob. Agents Chemother. 43(4): 727-37.

Opintan, J.A., Newman, M.J., Arhin, R.E., Donkor, E.S., GyansaLutterodt, M., Mills-Pappoe, W. 2015. Laboratory-based nationwide surveillance of antimicrobial resistance in Ghana. Infect. Drug Resist.8: 379-89.

Osman, K.M., Hassan, W.M., Mohamed, R.A. 2014. The consequences of a sudden demographic change on the seroprevalence pattern, virulence genes, identification and characterisation of integron-mediated antibiotic resistance in the Salmonella enterica isolated from clinically diarrhoeic humans in Egypt. Eur. J. Clin. Microbiol. Infect. Dis. 33(8): 1323-1337.

Randall, L.P., Cooles, S.W., Osborn, M.K., Piddock, L.J.V., Woodward, M.J. 2004. Antibiotic resistance genes, integrons and multiple antibiotic resistance in thirty- five serotypes of Salmonella enterica isolated from humans and animals in the UK. Journal of Antimicrobial Chemotherapy. 53: 208- 216.

Reshetneva, I.T., Per'ianova, O.V., Dmitrieva, G.M., Ostapova, T.S. 2015. Antibiotic resistance of salmonella spp. Isolated in the territory of the krasnoiarsk region.Gig Sanit. 94: 35-8.

Roberts, M.C.1996. Tetracycline resistant determinants: mechanisms of action, regulation of expression, genetic mobility and distribution. FEMS Microbiol. Rev. ,19: 1-24.

Samadi, N., Pakzad, I., Monadi, Sefidan, A., Hosainzadegan, H., Tanomand, A. 2015. Study of aminoglycoside resistance genes in enterococcus and salmonellastrains isolated from ilam and milad hospitals, iran. Jundishapur J. Microbiol. 8(4): e 18102.

Singh, A.K., Drolia, R., Bai, X., Bhunia, A.K. 2015. Streptomycin Induced Stress Response in Salmonella enterica SerovarTyphimurium Shows Distinct Colony Scatter Signatur PLoS One. 10 (8): e0135035.

Walker, R.A., Lindsay, E., Woodward, M.J. 2001. Variation in clonality and antibiotic- resistance genes among multi- resistant Salmonella enterica serotype Typhimurium phage- type U302 (MR U302) from humans, animals and foods. Microbiological Research 7: 13- 21.

Wasfy, MO., Frenck, R., Ismail, T.F., Mansour, H., Malone, J.L., Mahoney, F.J. 2002. Trends of multipledrug resistance among Salmonella ser type Typhi isolates during a 14year period in Egypt. Clin Infect. Dis. 35(10): 1265-8.

Weide-Botjes, M., Kobe, B., Lange, C., Schwarz, S. 1998. Molecular typing of Salmonella enterica subsp.enterica serovar Hadar: evaluation and application of different typing methods. Veterinary Microbiology 61: 215- 227.

Winokur, P.L., Brueggemann, A., DeSalvo, D.L., Hoffmann, L., Apley, M.D., Uhlenhopp, E.K., Pfaller, M.A., Doern, G.V. 2000. Animal and human multidrugresistant, cephalosporinresistant salmonellaisolates expressing a plasmid-mediated CMY-2 AmpC betalactamase. Antimicrob. Agents Chemother. 44(10): 2777-83. 